and analysing his results from sixteen continuous years of field experiments on the cotton crop. One side-issue during the Second World War from his work on other crops was to economize tonnage of merchant shipping by showing that imported artificial fertilizers produced much more food for the Egyptian than grain imported as such, which the British army had to bring in for its own use.

In 1949 Gracie started afresh in the dusty precinets of Amman with scanty resources, locating cultivable areas in the Jordan valley and the desert for the United Nations Arab Relief. In 1955 he transferred to Iran with better resources, where he created a large efficient laboratory organization for the United Nations Technical Assistance Board at Teheran. In 1958 he broke down from heat exhaustion, and retired to his Edinburgh home too late, dying there on May 31 of this year, leaving his wife Vera and one son.

With all his work done overseas, in countries not notorious for gratitude, merely increasing the resources of those countries by many acres of cultivation or many more tons of annual crop, he is likely to be one of those for whom there is but little remembrance-a depressing reflexion on those fine political projects for under-developed countries.

Gracie has been described as "a fierce seeker for truth, who could never suffer a rogue gladly", though he might tolerate a fool. He held on to his standards of precision, and made sure that his native assistants did the same.

Out of thirty years joint experience, a mutual friend writes of "the qualities of integrity, judgment, and application in good and indifferent health which he brought to his work. He had none of the narrowness with which specialists are sometimes charged; he was widely read in a diversity of subjects and worth listening to on any of them. Unbending in his uprightness with an inner light which lit for him so clearly the path he held in all affairs, yet he was not stiff; human, kindly, generous, and considerate, his friendship was one of the wholly good things a man could be blessed with". W. Lawrence Balls

\section{Dr. W. W. Francis}

Dr. William Willoughby Francis, librarian of the Osler Library at McGill University, Montreal, since 1929, died on August 10, aged eighty-one. A relative of Sir William Osler (his mother was Osler's first cousin, and Osler always spoke of him as a nephew), he was born at Montreal on April 2, 1878, and was educated at Trinity College School, Port Hope, and at Johns Hopkins University, Baltimore, where he graduated A.B. in 1898 and M.D. in 1902. After further study in Montreal, Baltimore, Vienna and London, he returned to Montreal in 1906. In 1912 he was appointed assistant editor of the Canadian Medical Association Journal and secretarytreasurer of the Canadian Medical Association, and in 1915 he went overseas with No. 3 Canadian General Hospital (McGill) as registrar. On demobilization in 1919, he lived in Oxford (where Osler was regius professor of medicine) before he became editor of the International Journal of Public Health at Geneva.

Dr. Francis's magnum opus was started in 1922, when he joined R. H. Hill, Archibald Malloch and Leonard Mackall in compiling the catalogue of Osler's magnificent library at Oxford. Working for 14-16 hr. a day for seven years, he succeeded nobly in inter- preting Osler's dream of an ideal biobibliography of epoch-making books and in staging it as a pageant. The catalogue under the title "Bibliotheca Osleriana" was published by the Oxford University Press in 1929, and the Osler Library at McGill was officially opened on May 29 of that year. Dr. Francis was president of the Medical Library Association during 1935-37, and honorary consultant to what was then called the Armed Forces Medical Library at Washington.

Bearing a striking resemblance to Osler in the shape of his head, his olive complexion, his dark, humorous eyes, the lightness of his step, and several of his mannerisms, 'Bill' or 'Billy' Francis was a charming man. Someone said of him that he was born under a dancing star and sang his way through life. His learning was vast and bizarre, but never pedantic, his memory was rich and retentive, his humour was spicy and puckish. His seemingly infinite leisure was at the disposal of the young and old who went to him for inspiration and for help. A classical scholar, a painstaking bibliographer ("his meticulosity exceeds anything you ever met with"Osler), and an unsurpassed writer of whimsical letters, Dr. Francis married in 1921 Hilda Colley, who survives him, with his daughter, Dr. Marian Kelen.

W. R. BrTt

\section{Prof. A. Preece}

The William Cochrane chair of metallurgy in the University of Durham at King's College, Nowcastle upon 'Tyne, became vacant last November with the untimely death of Prof. Archibald Preece at the age of fifty-three.

Preece was educated in South Wales and graduated from University College, Swansea, in 1926. He first joined the Pressed Steel Company of Great Britain as metallurgist, and later became a research officer to the South Wales Siemens Steel Research Association, but he returned to academic work in 1933 when he became a lecturer in metallurgy in the University of Leeds. There he pursued researches on the effect of high temperatures upon steel. The importance of his work was recognized by the award of the Sir Robert Hadfield Medal by the Iron and Steel Institute and by his promotion to a readorship in the University of Leeds in 1946.

In 1948 he was appointed to succeed C. E. Pearson as professor of metallurgy in King's College, Nowcastle upon Tyne. He took charge of a small but active department of teachers and research workers who carried out important work on the scaling of metals, temper brittleness and the solidification of steel castings, which were Preece's particular interests, though he encouraged others to work on a wide variety of different metallurgical topics. Just before his death he had the satisfaction of moving his Department into more commodious quarters and installing new equipment.

Prof. Preece was a deeply religious man who could be stern or kindly as the occasion demanded. He set himself extremely high standards both in his work and in his dealings with students and colleagues. Probably the most outstanding quality by which he will be remembered was his unwavoring integrity and his strict adherence to the truth as he saw it. $\mathrm{H}$ e was deeply devoted to his work and to his Department, and his sudden death was a great loss to all who came in contact with him.

A. F. Burstalix 